- RAM, REV. ADM. MACKENZIE, V. 12, N. 4 • SÃO PAULO, SP • JUL./AGO. 2011 • ISSN 1518-6776 (impresso) • ISSN 1678-6971 (on-line) • Submissão: 6 out. 2010. Aceitação: 25 abr. 2011. Sistema de avaliação: às cegas dupla (double blind review). UNIVERSIDADE PRESBITERIANA MACKENZIE. Walter Bataglia (Ed.), p. 105-126.

\title{
FLEXIBILITY AND UNCERTAINTY IN
}

\section{AGRIBUSINESS PROJECTS: INVESTING}

\section{IN A COGENERATION PLANTI}

\begin{abstract}
AUGUSTO CESAR ARENARO E MELLO DIAS
Doutorando em Administração de Empresas pelo Programa de Pós-Graduação em Administração de Empresas da Pontifícia Universidade Católica do Rio de Janeiro (PUC-Rio). Avenida República do Chile, 330, $21^{\circ}$ andar, Centro, Rio de Janeiro - RJ - Brasil - CEP 20031-170
\end{abstract}

E-mail: augustoarenaro@yahoo.com.br

\section{CARLOS DE LAMARE BASTIAN-PINTO}

Doutor em Administração de Empresas pelo Programa de Pós-Graduação em Administração de Empresas da Pontifícia Universidade Católica do Rio de Janeiro (PUC-Rio). Professor do Programa de Pós-Graduação em Administração de Empresas da Universidade do Grande Rio (Unigranrio). Rua da Lapa, 86, $9^{\circ}$ andar, Centro, Rio de Janeiro - RJ - Brasil - CEP 20021-180 E-mail: carbastian@gmail.com

\section{LUIZ EDUARDO TEIXEIRA BRANDÃO}

Doutor em Finanças pelo Programa de Pós-Graduação em Engenharia Industrial da Pontifícia Universidade Católica do Rio de Janeiro (PUC-Rio). Professor do Departamento de Administração da Pontifícia Universidade Católica do Rio de Janeiro. Rua Marquês de São Vicente, 225, Gávea, Rio de Janeiro - RJ - Brasil - CEP 22451-900

E-mail: brandao@iag.puc-rio.br

\section{LEONARDO LIMA GOMES}

Doutor em Finanças pelo Programa de Pós-Graduação em Engenharia Industrial da Pontifícia Universidade Católica do Rio de Janeiro (PUC-Rio).

Professor do Departamento de Administração da Pontifícia Universidade Católica do Rio de Janeiro. Rua Marquês de São Vicente, 225, Gávea, Rio de Janeiro - RJ - Brasil - CEP 22451-900 E-mail: leonardolima@iag.puc-rio.br 


\section{ABSTRACT}

Energy generation from biomass has become a source of increasing interest due to growing environmental concerns and the depletion of the world's fossil fuel reserves. In this paper we analyze a sugar and ethanol producing plant in Brazil which has both the option to expand and to add a cogeneration unit to allow the sale of surplus energy, generated by burning sugar cane bagasse, where the existence of the second option is conditional to the exercise of the first option. We model sugar, ethanol, and electricity prices as geometric mean reverting processes and apply the real options approach to determine the value of these managerial flexibilities, considering that these options have three distinct underlying assets. The option to expand production is a function of the expected future prices of sugar and ethanol, while, on the other hand, the decision to invest in the cogeneration plant will depend on the future prices of energy. Both decisions are modeled as American Compound Options over their respective underlying assets. The model is then solved using the non-censored binomial mean reverting lattice proposed by Bastian-Pinto, Brandão, and Hahn (20I0) using the software DPL ${ }^{\mathrm{TM}}$. The results indicate that a significant value can be derived from the flexibility to choose the optimal timing of investment in both options: the investment in the cogeneration unit adds an amount equivalent to the value of the expanding sugar and ethanol production, and represents up to $44 \%$ of the project's static NPV of R \$ I95.9 million. We conclude that given that only half of the sugar cane crushing mills currently have cogeneration units installed and given the increasing demand for clean and renewable sources of energy, this may indicate there is a significant potential for investment and further development of bioelectricity cogeneration power plants, and even in the retrofit of older cogeneration units, and that government incentives have been effective in contributing to this development.

\section{KEYWORDS}

Bioelectricity; Cogeneration; Real options; Flexibility; Mean reversion. 


\section{INTRODUCTION}

Concerns about global warming and high oil prices have spearheaded the search for alternate and more environmentally friendly sources of energy. One of the developments that has shown exceptional value is the increasing use of ethanol derived from biomass such as sugar cane, corn, beet, and wheat. As the world's largest producer of sugar cane, Brazil has benefited from this trend to become also the largest producer of ethanol after the United States.

An important by-product of sugar cane processing is the bagasse, which is the cellulose fiber that remains after the removal of water, sucrose, and other sugars and minerals. The bagasse represents up to $25 \%$ to $30 \%$ in weight of the sugar cane, and has traditionally been applied to generate the heat used in the production of sugar and ethanol. On the other hand, only one third of the total energy contained in a sugar cane plant corresponds to ethanol, while the remaining is due to the byproducts of the distillation process, such as bagasse. This implies that there is the potential to significantly increase the energy yield of the ethanol production process through a more effective use of the bagasse.

More recently, sugar cane mills have begun to use high pressure boilers where, rather than burning bagasse to generate heat directly, the bagasse is used as fuel to generate steam which can then be easily transformed into other forms of energy such as heat, traction, and electricity. This simultaneous production of electricity, thermal or mechanical energy from the same primary source is known as cogeneration, and represents a highly efficient process, as the use of the generated heat minimizes energy losses. Since almost no additional costs are involved, the revenue from cogeneration of bioelectricity from sugar cane processing plants has great potential to increase profitability and can reach yields of up to 60 to $80 \mathrm{kWh}$ per ton of sugar cane.

Aside from being a clean and renewable source of energy, in Brazil bagassebased bioelectricity requires minimal investment in transmission lines, since the sugar cane mills are largely located close to the consumption centers. Strategically, it is an energy source that can supplement Brazil's hydroelectric generation, which accounts for over $85 \%$ of the country's electrical energy matrix, since it is generated during the harvest in the dry season, when reservoir levels are at their lowest. In order to encourage the generation of electricity from sugar cane bagasse, the Brazilian government has taken steps to allow cogeneration units to sell surplus energy into the grid. As of 2010 , the aggregate capacity of bagasse cogeneration units in Brazil was 2,000 MW, representing about $3 \%$ of the total current electrical energy consumption of the country. On the other hand, a significant number of the 438 existing sugar cane mills still used less efficient low 
pressure boilers in their cogeneration plants or had no cogeneration capacity at all. This was expected to increase to $8,000 \mathrm{MW}$ by 2015 , due to new plants coming on stream and the retrofit of older plants (UNICA, 20IO).

The sugar cane industry, as it is typical of agribusiness projects, presents many uncertainties and significant flexibilities that require the use of option pricing methods to value these types of projects. Silva (I999), for example, used real options to analyze the effects of industrial policies in the agro-industrial chains. Figueiredo Neto (2003) analyzes land lease contracts as an option for growing crops, while Brobouski (2004) assesses a forestry partnership agreement with a floor price. Bastian-Pinto, Brandão, and Hahn (2009) also use the real options approach to analyze the flexibility to switch outputs between sugar and ethanol in a sugar cane processing plant. Schatzki (2003) considers the option to switch between agriculture production and reforestation that is available to landowners, while Musshoff and Odening (2005) examine the option to change from traditional to organic farming in Germany. Ge, Mourits, and Huirne (2005) calculate the flexibility in controlling diseases of livestock, and Scatasta and Wesseler (2008) assess the adoption of transgenic crops. Cardoso et al. (2009) also use the real options approach to study the case of the optimal timing to invest and disinvest in a coffee plantation in Brazil. None of these papers, however, analyze the impact of flexible investment in bioelectricity cogeneration units to the value of agricultural projects, and to the best of our knowledge this topic has not been addressed in the literature.

We analyze the case of an existing sugar cane mill that produces both sugar and ethanol, which has the option to expand the production and to retrofit its old cogeneration plant. The decision to expand is a function of the expected future prices of both sugar and ethanol, while the decision to invest in the new cogeneration plant will depend on the future prices of energy. Both decisions are modeled as American Compound Options over their respective underlying uncertainties, which are assumed to follow mean reverting diffusion processes, and we use the discrete binomial mean reverting tree model of Bastian-Pinto, Brandão, and Hahn (20IO) to model the uncertainties and embedded flexibilities. The model suggested provides not only the value added to the mill by these embedded flexibilities, but also the optimal timing to invest in the expansion and retrofit.

This paper is organized as follows. In the next section, we present an overview of the Brazilian sugar cane industry and the generation of bioelectricity. In section three, we introduce the case study of the project, and in section four we perform the real option analysis and present the results. Finally, in section five, we conclude. 


\section{THE SUGAR CANE INDUSTRY}

The sugar cane industry in Brazil is closely linked to the economic development of the country. Sugar cane was first brought to Brazil in I530 from the Portuguese islands of São Tomé e Madeira, and by the end of the sixteenth century, Brazil had already become the world's largest producer and supplier of sugar. Due to its high price and potential for generating wealth, sugar was one of the main reasons for the Dutch invasion of the Northeast region of the country in I624, where they remained for thirty years until they were eventually expelled by the Portuguese people thirty years later. With full knowledge of the sugar cane technology acquired during the period of the invasion, the Dutch developed this culture in the Dutch Guyana, nowadays called Suriname, which eventually spread it to other countries, contributing to the decline of this economic cycle in Brazil in the eighteenth century, when it fell to the fifth spot with only $8 \%$ of world production. Sugar was replaced by coffee as the most important crop until the twentieth century, when production picks up again to cover the internal market demands.

Currently, the Brazilian production of sugar cane is primarily concentrated on the South-Central region, which accounts for $88 \%$ of the production, and the Northeast, with the remaining I2\%. The vast Brazilian territory and its favorable climate provide a large supply of arable land, of which only 60 million hectares are currently used for agriculture and only 6 million hectares for sugar cane production. The development of new genetically engineered varieties and advances in the production technology have increased the competitiveness of Brazilian sugar cane industry to a point where sugar cane-based ethanol is the first renewable fuel that is able to compete with gasoline in terms of international costs. The sugar cane harvest of 2009/2010 was 590 million metric tons, which produced 33 million tons of sugar and 25 million cubic meters of ethanol (UNICA, 20IO). Brazil ranks first in production of sugar cane worldwide, first in sugar and second in ethanol, with this industry alone being responsible for $1.2 \%$ of the total GDP and for $26.5 \%$ of the country's agricultural GDP, employing over one million people.

Due to a strong international demand for sugar and the consolidation of ethanol as a cost efficient source of energy, the sugar cane industry has experienced significant growth in recent years, which has sparked the interest of major energy companies. In the beginning of 20I0, Cosan, the world's largest ethanol producer, with 23 sugar cane mills, I5 cogeneration power plants with I, $200 \mathrm{MW}$ capacity and a sugar cane crushing capacity of 60 million tons per year, announced a joint venture with Shell Oil, creating a venture with revenues of US\$20 
billion and over 4,000 gas stations, half of which as the result of the purchase of Brazilian assets of Exxon by Cosan in 2008. Odebrecht, a large petrochemical and construction group, also announced the purchase of Brenco, creating a US\$ 7 billion business with 40 million tons of sugar cane crushing and $500 \mathrm{MW}$ of cogeneration capacity. This industry trend towards consolidation is expected to reduce the number of producers to less than 20 in the next ten years.

About $40 \%$ of the sugar and $80 \%$ of the ethanol produced in Brazil is consumed domestically. Ethanol has been used as automotive fuel since I975, when the ProAlcool program was created. This program came as an attempt to reduce the country's vulnerability to the high prices of imported oil, and provided incentives for the production of ethanol and ethanol powered automobiles. A mixture of $20 \%$ to $25 \%$ of anhydrous ethanol to all gasoline was also mandated, which still remains in place to date. After a vigorous growth in the ig8os, the production of ethanol vehicles came to a halt as oil prices dropped and the government subsidies to ethanol producers were eliminated.

The introduction of flex fuel vehicles in 2003 renewed the demand for ethanol as an automotive fuel, and the consumption has increased significantly. Flex fuel vehicles are designed to operate on gasoline, ethanol, or any mixture of them, and according to the Brazilian National Association of Automobile Manufacturers - ASSOCIAÇÃO NACIONAL DOS FABRICANTES DE VEÍCULOS AUTOMOTORES (20I0), sales of flex fuel vehicles reached more than 2.5 million units in 2009 , representing $80 \%$ of all vehicles sales. About $85 \%$ of the current Brazilian automotive fleet consists of vehicles powered exclusively by gasoline, suggesting that there is significant room to increase the proportion of flex fuel vehicles as the fleet is renewed, something which will lead to an even greater demand for ethanol.

The sugar cane bagasse is the cellulose fiber that remains after the extraction of the nutrients. In the past, burning bagasse was seen as a way to eliminate the vast quantities generated in the process, with little regard for any form of efficiency either in the generation or the use of energy. Additionally, when manually harvesting the crop, producers typically set fire to the sugar cane fields in order to burn the sharp edges of the leaves to protect workers from cuts. This practice not only produces a large amount of atmospheric emissions, but also wastes the energy stored in the leaves.

Currently, sugar cane mills are designed with efficient cogeneration units that use high pressure boilers and are fully integrated to the production process. A greater concern with energy efficiency both in the use and generation process, and the use of modern automated harvesting technology which eliminates the need for burning the leaves, can significantly increase the energy yield of the mill, allowing the generation of surplus energy. The fact that sugar cane bioe- 
lectricity is produced during the harvest makes this source of energy particularly attractive, since it coincides with the dry season, when levels in the reservoirs of hydroelectric power plants are at their lowest. The sale of bioelectricity provides an important source of revenue to the sugar mill, as the capital investment is low, so even older mills can also be retrofitted in order to take advantage of this increase in energy generating capacity.

The production of bioelectricity has been made possible due to significant structural changes in the past two decades in the Brazilian Electricity Industry (BEI), which included the creation of a free market for energy and a series of initiatives which allowed surplus energy to be sold both in the free market for electricity and in a regulated environment. In I995, a federal law established the concept of the Free Consumer, where consumers with demand greater than 3 MW were allowed to purchase electricity directly from their supplier of choice. Then National Electrical Energy Regulatory Agency (Aneel) was created in I996, followed by the establishment of the National System Operator (ONS) in I998, which became responsible for the management of the national grid, including generation and transmission services. The Brazilian electrical energy wholesale market (CCEE) was also created at that time.

In 2004 , a new proposal for reforming the BEI was approved by the Congress. The main points of the new rules were the creation of two contracting environments (regulated and free) and the creation of a pool for electricity procurement by the distribution companies. In the regulated environment, distribution companies buy generation capacity for several years ahead (I5 years for thermal plants and 30 years for hydroelectric ones), and these companies are required to contract 100\% of their electricity needs as projected three and five years in advance. In the non-regulated market of electricity, generation and trading companies and free consumers are allowed to buy and sell electricity under bilateral contracts.

The first support measures for alternative energy sources, including bioelectricity, were created in 2004 under the Proinfa program of incentives, which offered 20-year fixed tariffs, subsidized capital, and other benefits. In 2007, Aneel established trading rules for alternative generation sources including biomass, allowing consumers with demand greater than $0.5 \mathrm{MW}$ to purchase electricity with $50 \%$ off in the distribution tariff. In 2008 , auctions for reserve electricity were created to enhance the security of the grid system. In the reserve contracts, all the consumption agents pay for the electricity, and the first reserve electricity auction in 2008 concerned biomass electricity contracts only.

Currently there are about 438 sugar cane mills in operation and 200 bagasse cogeneration projects being implemented or under analysis, which have the potential to add Io,000 MW of capacity by the year 2013 . 


\section{THE PROJECT}

We analyze an existing sugar cane mill with a nominal processing capacity of $\mathrm{I}, 000,000$ tons/year to produce sugar and ethanol with a production mix of $50 \%$ using typical industry data and parameters. Due to the use of low efficiency boilers, the energy produced from bagasse is enough only to power the mill, with no surplus capacity. The production can be expanded to I. 8 million tons per year in three years time, and once this expansion takes place, a more efficient cogeneration unit capable of providing surplus energy can also be built.

The forecasting period is Io years, with an expected growth rate of zero beyond the forecasting horizon and the corporate income tax rate is $34 \%$. Sugar and ethanol prices are forecasted based on historical price series. The project free cash flows $F$ are a function of the prices $P_{E}$ and $P_{S}$ of each commodity, the volume of sugar cane processed $V$, production yield of ethanol $Y_{E}$ and sugar $Y_{S}$, production costs of ethanol $C_{E}$ and sugar $C_{S}$, fixed costs $F C$, income taxes $T$, and depreciation $D$, as shown in Equation (I):

$$
\left.F_{t}=\left\{\left[\left(P_{E_{t}} Y_{E}-C_{E_{t}}\right) \times 50 \%+\left(P_{S_{t}} Y_{S}-C_{S_{t}}\right)\right] \times 50 \%\right] V-F C-D\right\}(\mathrm{I}-\mathrm{T})+\mathrm{D}
$$

As the mix of output products is assumed fixed (50\% for each product), in order to model a single uncertainty, an equivalent price $P_{E Q}$ for the $50 / 50$ production mix which considers the yield and different sales tax of each commodity is determined to be used as input in the analysis.

$$
P_{E Q_{t}}=\left(P_{E_{t}} Y_{E}+P_{S_{t}} Y_{S}\right) \times 50 \%
$$

Substituting this variable $\left(P_{E Q}\right)$ in Equation (I) we obtain:

$$
F_{t}=\left[\left(P_{E Q_{t}}-C_{E Q_{t}}\right) V-F C-D\right](\mathrm{I}-T)+D
$$

$$
\text { Where } C_{E Q_{t}}=\left(C_{E_{t}}+C_{S_{t}}\right) \times 50 \%
$$

The equity cost of capital is assumed to be $18.5 \%$ and the risk free rate is $7.0 \%$. With these parameters, under the traditional DCF analysis the value of the project is R\$ II2.7 million. For comparison purposes, if we assume that the expansion will occur at the end of the third year, the project value increases to R\$ I95.9 million. 


\section{REAL OPTION ANALYSIS OF PROJECT FLEXIBILITIES}

The previous analysis does not take into account the value of the option to delay the expansion beyond year three or the possibility of investing in a cogeneration unit that will allow the project to sell surplus electricity into the power grid. The expansion of sugar cane processing capacity to I. 8 million tons per year requires an additional investment of $\mathrm{R} \$ 26$ million and a ramp up phase of three years, and the decision to expand the project will depend both on the prices of sugar and ethanol and the cost of this expansion.

The cogeneration plant involves an investment of $\mathrm{R} \$ 38$ million in plant and equipment, and due to its high cost and economies of scale, it is conditioned to the prior expansion of capacity to I.8 million tons. It is assumed that both investments will only be executed if expected prices of sugar, ethanol and electricity allow adequate return to the shareholders.

The free cash flows (FCF) from the sale of surplus electricity are distinct from the FCF of the sugar and ethanol sales, as bagasse is a by-product of the of the sugar cane crushing process, so no variable cost are involved. Project specific fixed costs are also minimal and therefore surplus electricity FCF is given by Equation (3):

$\left.F_{E E_{t}}=P_{E E_{t}} Y_{E E} V-D_{E E}\right)(\mathrm{I}-T)+D_{E E}$

Where

$F_{E E_{t}}:$ Free cash flow of surplus electrical energy in year $t$;

$P_{E E_{t}}$ : Price of electricity in year $t$

$Y_{E E}$ : Electricity yield per ton of sugar cane;

$V$ : Volume of sugar cane processed;

$D_{E E}$ : Depreciation of investment in cogeneration;

$T$ : Income tax rate.

\subsection{PROJECT EXPANSION}

The main drivers of the option to expand are the future expected prices for sugar and ethanol. The daily prices of sugar and ethanol paid to producers, published by the Center of Advanced Studies in Applied Economics of University of São Paulo (Centro de Estudos Avançados em Economia Aplicada - Cepea/USP) are shown in Graphics I and 2. 


\section{GRAPHIC I}

SUGAR PRICES (R\$/50 KG)

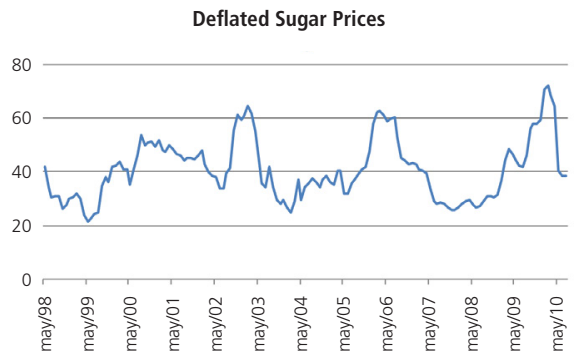

Source: Centro de Estudos Avançados em Economia Aplicada/USP (2009).

\section{GRAPHIC 2}

ETHANOL PRICES (R\$/LITER)

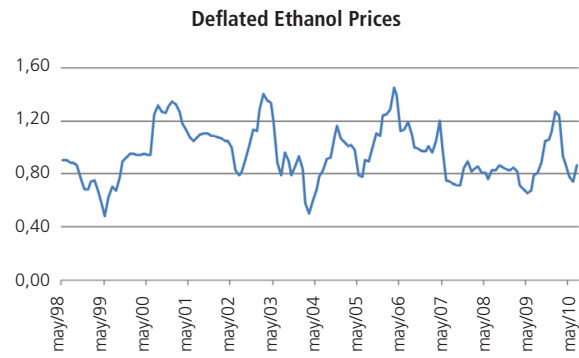

Source: Centro de Estudos Avançados em Economia Aplicada/USP (2009).

The equivalent price $\left(P_{E Q}\right)$ considering the price of sugar and ethanol, their yields and direct taxes was modeled as a Mean Reverting Diffusion Process, as follows:

$$
d P=\eta(\log [\bar{P}]-\log [P]) P d t+\sigma P d z
$$

Where:

$\eta$ : Is the mean reversion coefficient parameter of the process;

$\sigma$ : Is the volatility of the process;

$\bar{P}$ : Is the equilibrium level to which the process reverts in the long run;

$d z$ : Is the standard Weiner increment.

Using the price series of sugar and ethanol described above, a series of equivalent prices $\left(P_{E Q}\right)$ was calculated and the required parameters were derived by running the following regression:

$$
\log \left[P_{t}\right]-\log \left[P_{t-\mathrm{I}}\right]=\beta_{\circ}+\beta_{\mathrm{I}} \log \left[P_{t-\mathrm{I}}\right]+\varepsilon
$$

The mean reversion coefficient $\eta$ is obtained from the regression output as

$$
\eta=\frac{-\log \left(\beta_{\mathrm{I}}+\mathrm{I}\right)}{\Delta t}, \text { the volatility is given by } \sigma=\sigma_{\varepsilon} \sqrt{\frac{2 \log \left(\beta_{\mathrm{I}}+\mathrm{I}\right)}{\Delta t\left[\left(\beta_{\mathrm{I}}+\mathrm{I}\right)^{2}-\mathrm{I}\right]}}
$$


Where $\sigma_{\varepsilon}^{2}$ is the variance of the regression's errors, and the long term mean is given by

$$
\bar{P}=\exp \left[-\frac{\beta_{\circ}}{\beta_{\mathrm{I}}}+\frac{\sigma^{2}}{2 \eta}\right] .
$$

For option pricing purposes, the risk neutral measure must be used. In mean reverting models, this also involves a downward adjustment to the long term mean. For a more detailed discussion of the parameter definition and the use of mean reverting models for option pricing, we refer the reader to Schwartz (I997). The plotted regression line and its corresponding equation for the data can be seen in Graphic 3 .

\section{GRAPHIC 3}

\section{EQUIVALENT PRICES (PEQ) REGRESSION}

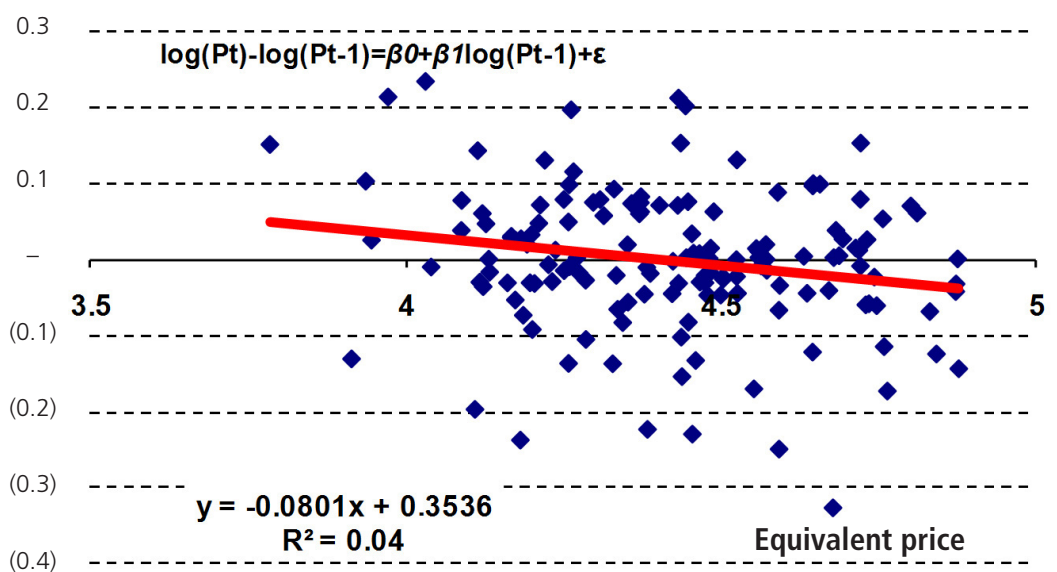

Source: Developed by the authors.

The results of parameter definition for $P_{E Q}$ are listed in Table I.

\section{TABLE I}

PARAMETERS FOR PEQ PROCESS

\begin{tabular}{cccc}
\hline$P_{E Q_{0}}$ & $\bar{P}_{E Q_{0}}{ }^{*}$ & $\eta$ & $\sigma$ \\
\hline$R \$ / t$ & $R \$ / t$ & year & year \\
\hline 131.04 & 61.5 & 1.0019 & $32.87 \%$ \\
\hline
\end{tabular}

Source: Developed by the authors. 
To obtain the option value of the expansion, we model the sugar/ethanol equivalent price uncertainty as a discrete mean reverting binomial lattice, where the values at each branch are the free cash flows of the project that correspond to the prices in each state. The discounted expected value of these free cash flows provides the value of the project. The model developed by these authors is a non-censored mean reverting binomial lattice similar to the GBM lattice of Cox, Ross, and Rubinstein (1979) but with varying values of the probability $p$ for the up move. The model parameters are as follows:

Consider: $x_{t}+x^{*}{ }_{t}=\log \left(P_{t}\right)$,

Where:

$x_{t}$ is the deterministic part of the process;

$x{ }_{t}$ is the stochastic part, modeled as an Ornstein Uhlenbeck arithmetic mean reversion, with long term mean $=0$, and starting value also $=0$;

$x^{*}{ }_{t}$ is modeled into a mean reverting lattice, with:

$$
\begin{aligned}
& x^{*+}=x^{*}+\sigma \sqrt{\Delta t} \\
& x^{*-}=x^{*}-\sigma \sqrt{\Delta t} \\
& p_{x_{t}}=\frac{\mathrm{I}}{2}+\frac{\mathrm{I}}{2} \frac{\eta\left(-x_{t}^{*}\right) \sqrt{\Delta t}}{\sqrt{\eta^{2}\left(-x_{t}^{*}\right)^{2} \Delta t+\sigma^{2}}}
\end{aligned}
$$

Adding the zero mean lattice values $x_{t}^{*}$ to the deterministic values of $x_{t}$, we obtain a lattice describing the mean reversion process, with values at each nod after $i$ up movements, and $j$ down movements will be:

$$
x_{(i, j)}=\bar{x}\left(\mathrm{I}-e^{-\eta(i+j) \Delta t}\right)+x_{0} e^{-\eta(i+j) \Delta t}+(i-j) \sigma \sqrt{\Delta t}
$$

To model the geometric mean reversion process describing the behavior of prices such as $P_{E Q}$, we use:

$$
P_{(i, j)}=\exp \left[x_{(i, j)}\right] \text {, and: } \bar{x}=\log [\bar{P}]-\frac{\sigma^{2}}{2 \eta}-\frac{\lambda}{\eta},
$$

already in the risk neutral form, where $\lambda$ is the premium risk of the process. The value of $\bar{x}$ was estimated through numerical procedures, by equating the 
present value of the base project discounting cash flows at the risk adjusted rate (Wacc) and that of risk neutral cash flows (adjusted through this risk premium $\lambda$ ) discounted at the risk free rate. The probability $p$ of an up move at each node is calculated by Equation. This Mean Reverting lattice was then modeled with the aid of the DPL ${ }^{\mathrm{TM}}$ program and the option to expand modeled as a recurring decision opportunity between years two and nine. Figure I illustrates the first six years of the binomial tree model used.

\section{FigurE I}

SUGAR AND ETHANOL PRODUCTION EXPANSION MODEL

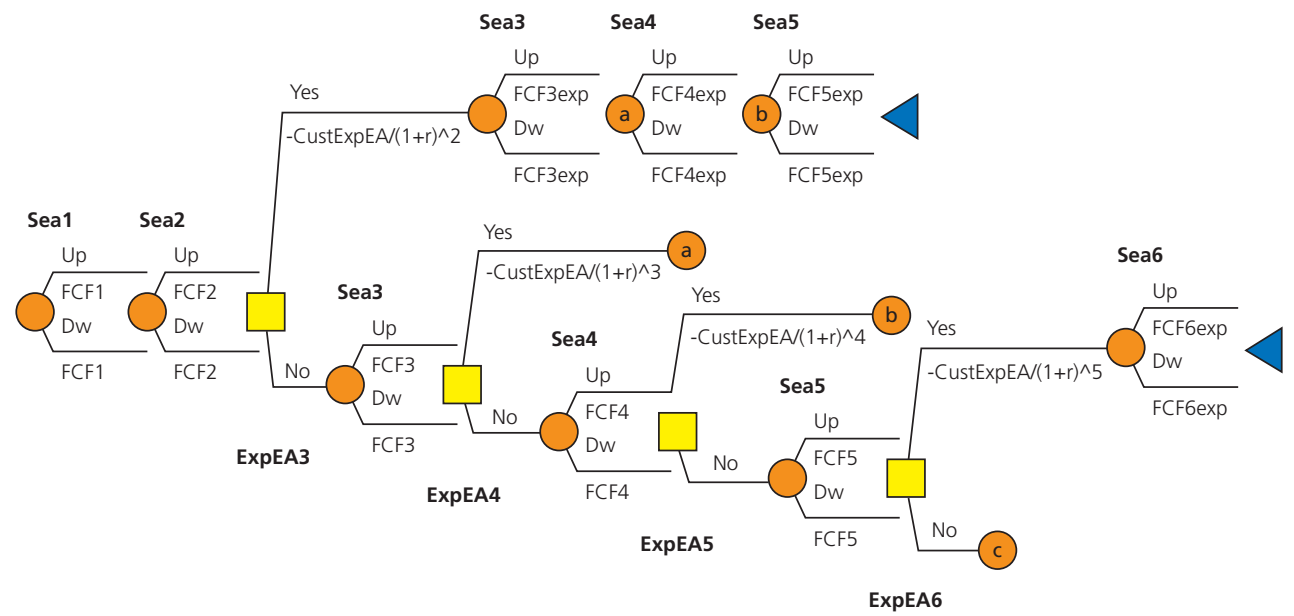

Source: Developed by the authors.

The value of the project considering the option to expand sugar and ethanol production is $\mathrm{R} \$ 237.3$ million, as shown in Figure 2, which compares to the value of R\$ I95.9 million of the static analysis that assumes a mandatory expansion in year three. This represents a value of R \$ 4I.4 million for the option to defer the expansion, which is significant, and implies that early exercise may not be optimal in this case. The analysis of the probability of the expansion occurring shows that flexibility to defer to the latter years is what creates option value: probability of exercise in year eight is $38 \%$ and $46 \%$ in year ten. 


\section{FIGURE 2}

VALUE OF THE OROJECT WITH SUGAR AND ETHANOL EXPANSION

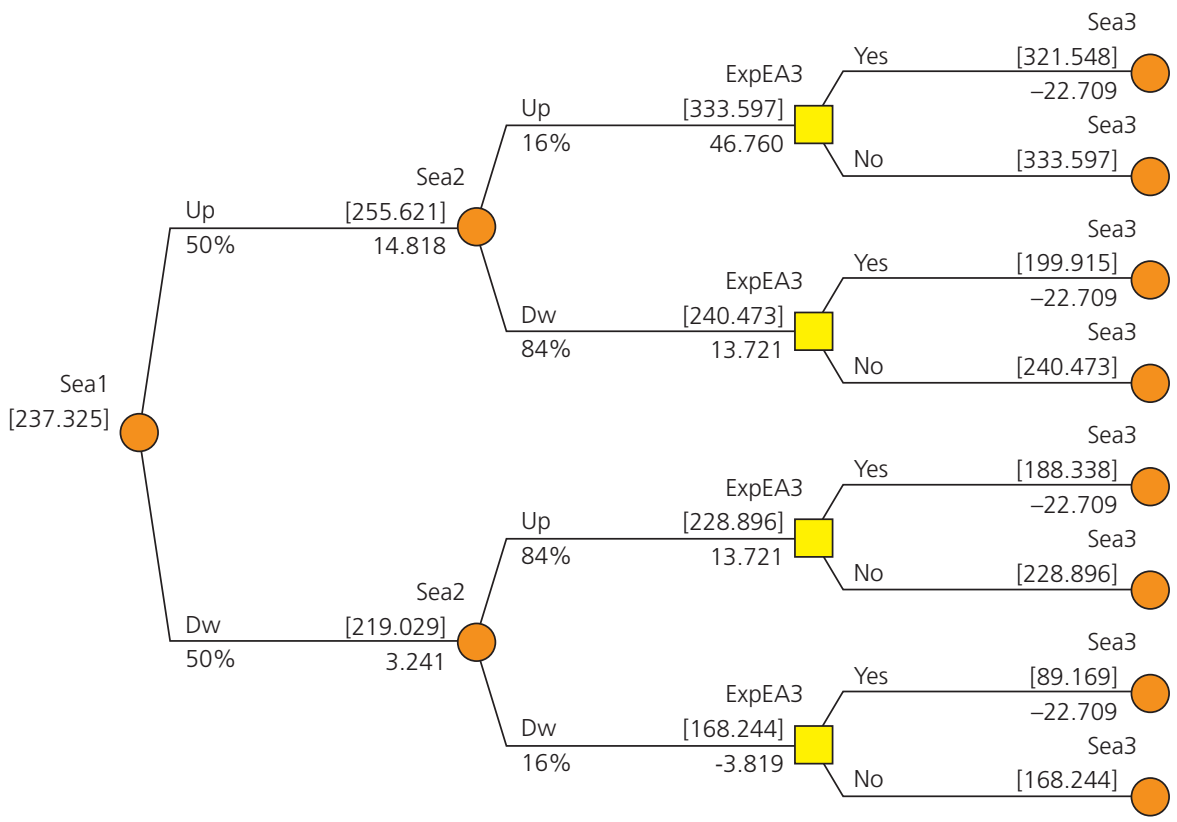

Source: Developed by the authors.

\subsection{INVESTMENT IN COGENERATION}

Once the decision to expand the production has been made, the company has the option to invest in a cogeneration plant that will allow the production of surplus energy to be sold. We assume that once the cogeneration unit becomes available, the company will enter into a long term sales contract at the prevailing spot price of energy at the time, and therefore, no further electricity price uncertainties will exist for the project. The daily spot energy prices (Preço de Liquidação de Diferenças - PLD) informed by the Brazilian Electrical Energy Clearing Chamber (CCEE) are shown in Graphic 4. 


\section{GRAPHIC 4}

\section{PLD ENERGY BRAZIL DAILY SPOT PRICES}

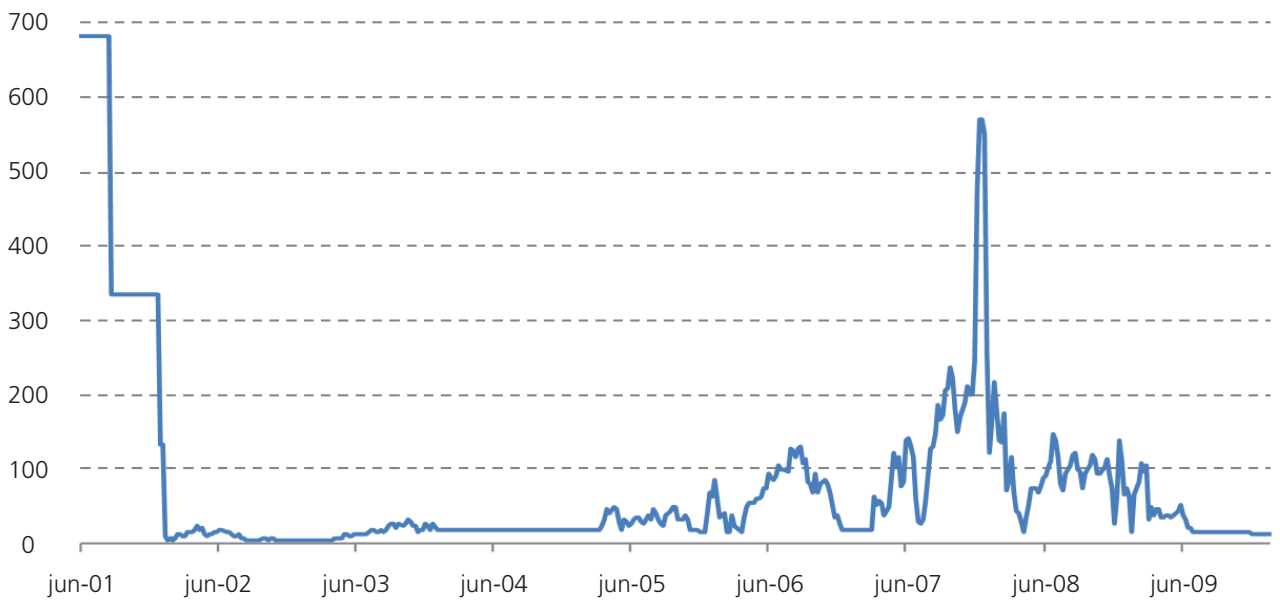

Source: Câmara de Comercialização de Energia Elétrica - CCEE (20IO).

As of January 20I0, the spot price of energy was at its lowest level (about $\mathrm{R} \$$ I2.80/MW, or US\$ 7.00/MW) since higher than normal rainfalls had left the hydro power plants reservoirs filled to capacity. At these exceptionally low price levels, most energy investments will yield negative returns. Nonetheless, the option to invest in such projects may still yield positive results as the stochastoc energy price will tend to revert to their long term mean of $120 / \mathrm{MW}$. We model future electricity $\left(P_{E E t}\right)$ prices as a MRM diffusion process using the same framework as with the equivalent sugar-ethanol price. Parameters for this process are listed in Table 2.

\section{TABLE 2}

\section{PARAMETERS FOR PEN PRO}

\begin{tabular}{cccc}
\hline$P_{E E_{0}}$ & $\bar{P}_{E E}{ }^{*}$ & $\eta$ & $\sigma$ \\
\hline $\mathrm{R} \$ / \mathrm{MW}$ & $\mathrm{R} \$ / \mathrm{MW}$ & year & year \\
\hline 20.0 & 119.2 & 2.37 & $57.53 \%$ \\
\hline
\end{tabular}

* Risk neutral adjusted long term mean.

Source: Developed by the authors. 
Once the stochastic electricity prices are modeled, we use Equation (3) to determine the corresponding project free cash flows in each year and for each possible price levels. Given that hydro power is the main source (90\%) of electrical energy in Brazil, the main factor driving prices is the amount of local rainfall in any particular year. On the other hand, ethanol and sugar prices are determined by international prices, which take into account crop output in the main producing countries worldwide. As such, these prices are uncorrelated, and options written on these underlying uncertainties can be valued independently. A stand alone analysis of the cogeneration unit, assuming an investment of $\mathrm{R} \$ 38.0$ million that occurs between years 4 and Io, and with no expected growth beyond the forecasting horizon, has a net present value (year o) of $\mathrm{R} \$ 44.3$ million.

Due to economies of scale, on the other hand, the investment in the cogeneration plant can only occur after the sugar-ethanol plant has undergone expansion. Therefore, the option to invest in the cogeneration project is conditional to the expansion option of the original sugar-ethanol project being exercised, creating a compound option problem, which requires both options to be valued simultaneously. Both options were then modeled using the same DPL ${ }^{\mathrm{TM}}$ software used in the valuation of the sugar and ethanol expansion option. Figure 3 shows the first five years of the complete lattice model.

\section{FIGURE 3}

\section{SUGAR AND ETHANOL EXPANSION AND}

COGENERATION OPTIONS MODEL

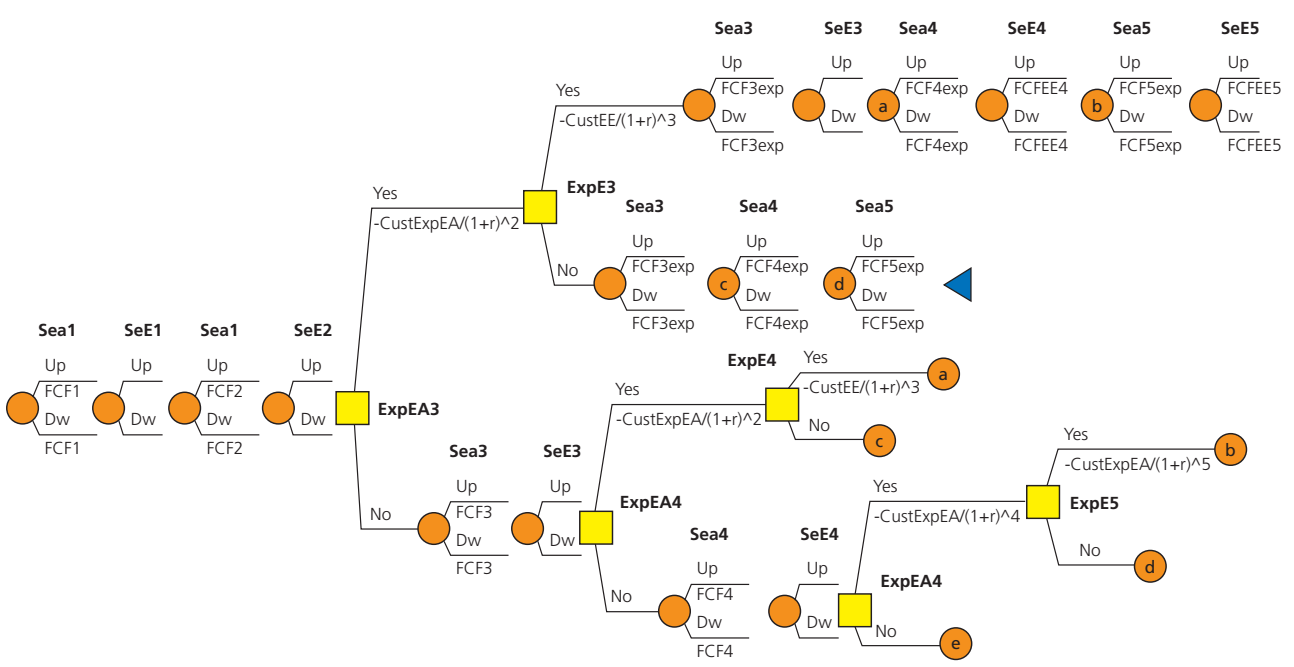

Source: Developed by the authors. 
With this framework, the option to invest in a cogeneration unit between the fourth and tenth year of the project, the unit increases the project value to $R \$ 275.9$ million, an increase of $R \$ 38.6$ million, over the value of the project considering the sugar-ethanol expansion option only. It is interesting to note that when analyzed as a compound option, there is a decrease in value of $\mathrm{R} \$ 5.8$ million over the stand alone cogeneration project. This is due to the conditional aspect of the cogeneration unit option on sugar/ethanol option. As the first option - delaying the base case expansion - gains value, the second option - investing in cogeneration - diminishes in value. But considering the value of both options together, these have a value of $\mathrm{R} \$ 79.92$ million ( $\mathrm{R} \$ 275.9$ minus $\mathrm{R} \$ \mathrm{I} 95.9$ million of the year 3 expanded base case project), or an increase in $40.8 \%$ in value. The optimal investment time for the cogeneration unit is also concentrated on the final years of the projection horizon: 10\% in year $5,6 \%$ in year 7 , and $73 \%$ in year 9. These probabilities are determined by running the simulation model with the corporate Wacc rate, rather than the risk free rate, so that the correct probabilities can be computed, rather than risk neutral probabilities.

The sensitivity analysis for the long term mean of the ethanol and sugar equivalent price shows that the value of the project is very sensitive to changes in this variable. For a negative variation of $20 \%$, which brings this value below R $\$ 50.00$, the project has negative NPV, considering that the initial capital investment is R\$ Ioo million (Graphic 5).

\section{GRAPHIC 5}

SENSITIVITY LONG TERM MEAN OF SUGAR AND

ETHANOL EQUIVALENT PRICE

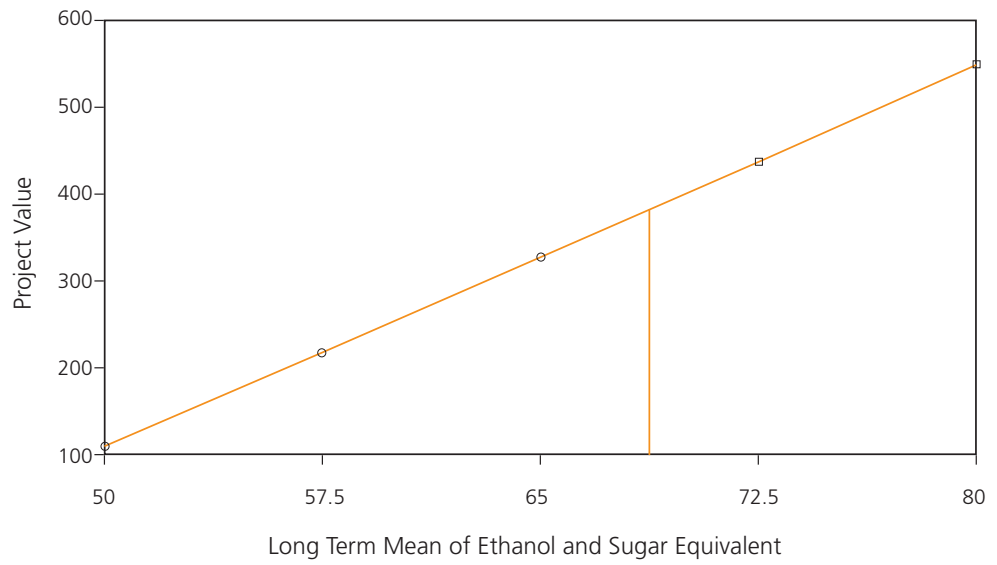

Source: Developed by the authors. 
On the other hand, the sensitivity analysis of the long term mean of spot electricity prices (Graphic 6 ) indicates that the impact on the project is not as severe as is the case of sugar and ethanol, which is reasonable, since the volumes and revenues from surplus electricity are much smaller than those of sugar and ethanol.

GRAPHIC 6

SENSITIVITY TO LONG TERM MEAN OF ELECTRICITY PRICES

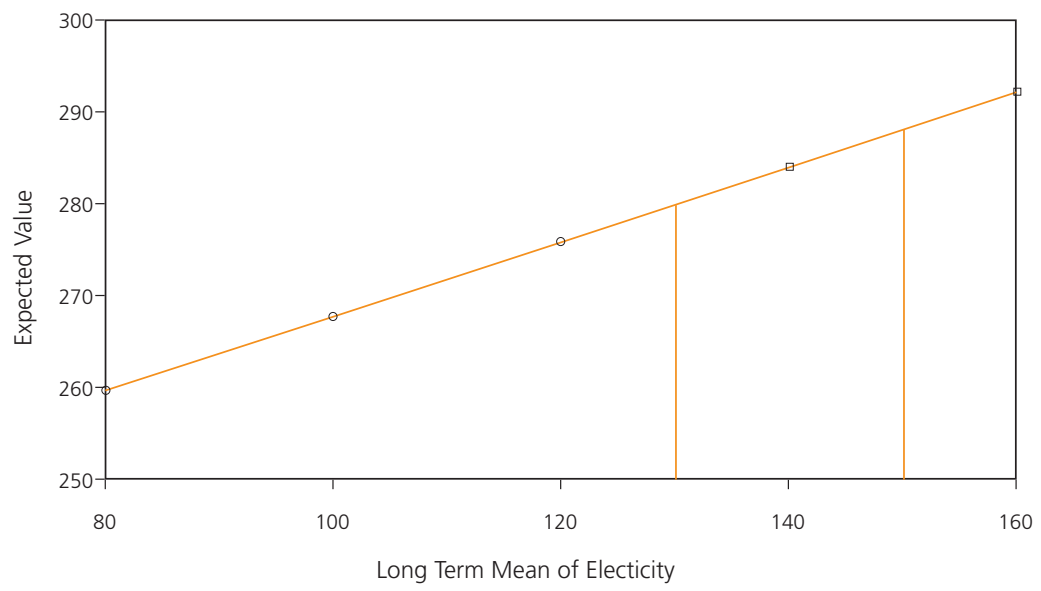

Source: Developed by the authors.

\section{CONCLUSION}

We analyzed a sugar cane mill that has significant embedded flexibilities to expand production and to add a cogeneration unit that will allow it to sell surplus electricity. We apply the real options approach to determine the value of this managerial flexibility, considering that these options have three distinct underlying assets. While the key uncertainties for the expansion of the mill are the future prices of sugar and ethanol, the investment in the cogeneration plant will depend on the evolution of the future prices of energy. We model these simultaneous uncertainties as mean reverting processes, and the project flexibilities as two distinct compound American Compound Options. The model is then solved using the non-censored binomial mean reverting lattice proposed by BastianPinto, Brandão, and Hahn (20I0) using the DPL ${ }^{\mathrm{TM}}$ software.

The results show that the flexibility to choose the optimal time to invest in plant expansion adds R $\$ 4$ I.4 million in value, or $44 \%$ of the project NPV of $\mathrm{R} \$ 95.9$ million. The cogeneration unit adds an almost equivalent amount, which is significant, considering that cogeneration is not the core business of 
the sugar cane mill. Given that only half of the sugar cane crushing mills currently has cogeneration units installed and the increasing demand for cleaner and renewable sources of energy, this may indicate that there is a significant potential for investment and further development of bioelectricity cogeneration power plants, and even in the retrofit of older cogeneration units. Government incentives have been effective in contributing for this development which is growing at a very fast pace.

However, a few restrictions apply. Parameter determination is a problem that affects any valuation model, and real option analysis is not immune to this. The sensitivity analysis indicates that the results are very sensitive to the input parameters of the model, in particular to the level of the long term mean prices of the outputs, and small variations in this parameter may lead to different results. On the other hand, additional flexibilities that are inherent to this type of project were not considered in our analysis. Rather than a fixed 50/50 proportion of sugar and ethanol, the producer may have the option to change this proportion and switch outputs in response to relative variations in prices.

\section{FLEXIBILIDADE E INCERTEZA EM PROJETOS DE AGRONEGÓCIOS: INVESTINDO NUMA PLANTA DE COGERAÇÃO}

\section{RESUMO}

A geração de energia a partir da biomassa tem se tornado uma fonte crescente de interesse em função das crescentes preocupações com a possível exaustão das reservas de combustíveis fósseis mundiais. Neste artigo, analisamos uma planta de produção de açúcar e etanol no Brasil, a qual possui tanto uma opção de expansão quanto uma de agregar uma unidade de cogeração, a qual permitiria a venda de energia excedente, gerada a partir da queima do bagaço da cana-de-açúcar, e a segunda opção é condicionada pela implementação da primeira. Modelamos os preços de açúcar, etanol e energia elétrica como processos de reversão à média geométrica e aplicamos a abordagem de opções reais para quantificar essas flexibilidades gerenciais, considerando que essas duas opções possuem diferentes ativos subjacentes. A opção de expansão de produção é função do valor esperado dos preços futuros de açúcar e etanol, enquanto a opção de investir numa planta de cogeração irá depender dos preços futuros de energia elétrica. Ambas as decisões são modeladas como opções americanas compostas sobre seus respectivos ativos subjacentes. O modelo é resolvido utilizando uma árvore binomial 
recombinante não censurada para reversão à média proposta por Bastian-Pinto, Brandão e Hahn (20I0) usando o software DPL ${ }^{\mathrm{TM}}$. Os resultados indicam que a flexibilidade de escolha do momento ótimo de investir em ambas as opções de expansão gera um valor significativo: o investimento na unidade de cogeração agrega um valor equivalente ao valor da expansão de produção de açúcar e etanol, e representam até 44\% do VPL tradicional de R\$ I95,9 milhões do projeto. Concluímos que, dado que somente a metade das usinas de processamento de cana-de-açúcar existentes hoje no Brasil tem unidades de cogeração instaladas, e em razão também da sempre crescente demanda por fontes limpas e renováveis de energia, isso pode indicar que existe um potencial significativo para investimento e desenvolvimento de unidades de cogeração de bioeletricidade, assim como do retrofit de usinas mais antigas, e que os incentivos do governo vêm sendo efetivos na contribuição a esse desenvolvimento.

\section{PALAVRAS-CHAVE}

Bioeletricidade; Cogeração; Opções reais; Flexibilidade; Reversão à média.

\section{FLEXIBILIDAD Y INCERTIDUMBRE EN PROYECTOS DE AGRONEGOCIOS: LA INVERSIÓN EN UNA PLANTA DE COGENERACIÓN}

\section{RESUMEN}

La generación de energía de la biomasa se ha convertido en una fuente creciente de interés en vista de la creciente preocupación sobre el posible agotamiento de los combustibles fósiles en todo el mundo. En este artículo nos fijamos en una planta productora de azúcar y etanol en Brasil, que tiene tan bien una posibilidad de expansión como una opción de agregar una unidad de cogeneración que le permita la venta de energía excedente generada por la quema del bagazo de caña de azúcar, mientras que la segunda opción es dependiente de la primera. Fueron modelados los precios del azúcar, etanol y electricidad, como procesos de reversión a la media geométrica y fue aplicado el enfoque de opciones reales para cuantificar esta flexibilidad en la gestión, ya que estas dos opciones tienen diferentes activos subyacentes. La opción de expandir la producción es una función del valor esperado de los precios de futuros de azúcar y etanol, mientras que la opción de invertir en una planta de cogeneración dependerá del precio futu- 
ro de la electricidad. Ambas decisiones se modelan como opciones americanas compuestas sobre sus activos subyacentes. El modelo se resuelve utilizando un árbol binomial recombinante para reversión sin censura a la media propuesta por Bastian-Pinto, Brandão y Hahn (20I0) utilizando el software DPL ${ }^{\mathrm{TM}}$. Los resultados indican que la flexibilidad de escoger el momento óptimo para invertir en las dos opciones de expansión genera un valor significativo: la inversión en la unidad de cogeneración añade un valor igual a la expansión de la producción de azúcar y etanol, y representan a 44\% del VAN proyectado tradicional de \$ 195,900,000. Se concluye que, dado que sólo la mitad de las plantas de caña de azúcar en Brasil tienen unidades de cogeneración instaladas, y también dada la demanda cada vez mayor de fuentes limpias y renovables de energía, esto puede indicar que existe un potencial importante para inversiones y desarrollo de unidades de cogeneración de bioelectricidad, así como de adaptación de las plantas más viejas, y que los incentivos que el gobierno ha dado son una contribución efectiva en este desarrollo.

\section{PALABRAS CLAVE}

Bioelectricidad; Co-generación; Opciones reales; Flexibilidad; Reversión a la media.

\section{REFERENCES}

ASSOCIAÇÃO NACIONAL DOS FABRICANTES DE VEÍCULOS AUTOMOTORES - ANFAVEA. Disponível em: <http://www.anfavea.com.br/Index.html>. Acesso em: 20 jan. 2010.

BASTIAN-PINTO, C.; BRANDÃO, L.; HAHN, W. J. Flexibility as a source of value in the production of alternative fuels: the ethanol case. Energy Economics, Amsterdam, v. 3I, n. 3, p. 4II-422, May 2009 .

A non-censored binomial model for mean reverting stochastic processes. In: ANNUAL INTERNATIONAL CONFERENCE ON REAL OPTIONS, I4., 20Iо, Rome. Proceedings... Rome: 20Iо. Disponível em: <http://www.realoptions.org/papers2oı。/index.html>. Acesso em: IO nov. 2010.

BROBOUSKI, W. J. P. Teoria das opções reais aplicada a um contrato de parceria florestal com preço mínimo. 2004. 85 f. Dissertação (Mestrado em Métodos Numéricos em Engenharia)-Escola de Engenharia, Universidade Federal do Paraná, Curitiba, 2004.

CÂMARA DE COMERCIALIZAÇÃO DE ENERGIA ELÉTRICA - CCEE. Brasil. Disponível em: $<$ http://ccee.org.br>. Acesso em: I8 fev. 20 Io.

CARDOSO, C. E. et al. Real options analysis of coffee planting in Brazil: when to get in or get out. In: ANNUAL INTERNATIONAL CONFERENCE ON REAL OPTIONS, I3., 2009, Braga, Santiago. Proceedings... Braga, Santiago: 2009. Disponível em: <http://www.realoptions.org/ abstracts_2009.html>. Acesso em: 8 set. 2009 . 
- RAM, REV. ADM. MACKENZIE, V. 12, N. 4 •

SÃO PAULO, SP • JUL./AGO. $2011 \bullet$ p. 105-126 •ISSN 1518-6776 (impresso) • ISSN 1678-6971 (on-line)

CENTRO DE ESTUDOS AVANÇADOS EM ECONOMIA APLICADA - Cepea. Disponível em: $<$ http://cepea.esalq.usp.br>. Acesso em: I4 nov. 2009.

COX, J. C.; ROSS, S. A.; RUBINSTEIN, M. Option pricing: a simplified approach. Journal of Financial Economics, Amsterdam, v. 7, n. 3, p. 229-263, Sept. I979.

FIGUEIREDO NETO, L. F. Análise e gestão de projetos: proposta de aplicação da teoria de opções reais na produção agropecuária. 2003. Tese (Doutorado em Engenharia de Produção)-Escola Politécnica, Universidade de São Paulo, São Paulo, 2003.

GE, L.; MOURITS, M. C. M.; HUIRNE, R. B. M. Valuing flexibility in the control of contagious animal disease. In: ANNUAL INTERNATIONAL CONFERENCE ON REAL OPTIONS, 9., 2005, Paris. Proceedings... Paris, 2005. Disponível em: <http://www.realoptions.org/abstracts_2005.html>. Acesso em: 8 set. 2009 .

MUSSHOFF, O.; ODENING, M. Adoption of organic farming: a positive real options analysis. In: ANNUAL INTERNATIONAL CONFERENCE ON REAL OPTIONS, 9., 2005, Paris. Proceedings... Paris, 2005. Disponível em: <http://www.realoptions.org/abstracts_2005.html>. Acesso em: 8 set. 2009.

SCATASTA, S.; WESSELER, J. Real options and the adoption of transgenic crops: an intertemporal perspective. In: ANNUAL INTERNATIONAL CONFERENCE ON REAL OPTIONS, I2., 2008, Rio de Janeiro. Proceedings... Rio de Janeiro, 2008. Disponível em: <http://www.realoptions.org/ abstracts_2008.html>. Acesso em: Io nov. 2010.

SCHATZKI, T. Options, uncertainty and sunk costs: an empirical analysis of land use change. Journal of Environmental Economics and Management, Amsterdam, v. 46, n. I, p. 86-I05, July 2003. SCHWARTZ, E. S. The stochastic behavior of commodity prices: implications for valuation and hedging. The Journal of Finance, Berkeley, v. 52, n. 3, p. 923-973, July I997.

SILVA, R. N. Ajustamentos na política comercial brasileira e seus efeitos nas cadeias agroindustriais. I999. 35 f. Tese (Doutorado em Economia Rural)-Departamento de Economia Rural, Universidade Federal de Viçosa, Viçosa, I999.

UNIÃO DA INDÚSTRIA DA CANA-DE-AÇÚCAR - UNICA. Production of sugar cane, sugar and ethanol. Disponível em: <http://english.unica.com.br/dadosCotacao/estatistica>. Acesso em: 2 jan. 2010. 